\title{
Pobreza Infantil / Child Poverty
}

https://doi.org/10.21814/uminho.ed.36.50

\section{Fernando Diogo}

Universidade dos Açores e CICS.NOVA - Centro Interdisciplinar de Ciências Sociais da Faculdade de Ciências Sociais e Humanas, Universidade NOVA de Lisboa (NOVA FCSH), Portugal 



\section{Pobreza Infantil}

A pobreza infantil é uma questão complexa e central na sociedade portuguesa, como noutras sociedades europeias.

A sua complexidade está associada à polémica à volta da sua definição e é, em primeiro lugar, uma questão epistemológica. Com efeito, parte dos estudiosos sobre a pobreza rejeitam a ideia de pobreza infantil, preferindo falar em pobreza das crianças.

Esta polémica radica numa ideia importante: as crianças não são titulares de rendimentos, são pobres no seio de agregados familiares pobres. Este argumento deriva da forma como a pobreza é calculada na União Europeia (UE). Assim, o Eurostat considera como pobres todos os indivíduos que tenham um rendimento abaixo de $60 \%$ da mediana do rendimento nacional por adulto equivalente. Isto significa que os dados de rendimento a partir dos quais a pobreza é calculada são recolhidos por Agregado Doméstico Privado (ADP), sendo depois individualizados de acordo com uma escala de adulto equivalente (a da OCDE modificada).

Este processo de conversão coloca um novo problema que desafia a definição de pobreza infantil: pressupõe a igual distribuição dos recursos no agregado doméstico o que, de acordo com a literatura, tende a subestimar a pobreza das crianças e das mulheres (Bastos, 2015).

Acresce que a definição de pobreza infantil é desafiada por outros fatores. Desde logo pelo facto de resultar da justaposição de dois conceitos, pobreza e infância, que já de si são complexos. Uma ilustração significativa dessas dificuldades tem a ver com a definição etária de criança. Nos estudos sobre a pobreza infantil tende-se a mobilizar a definição da convenção universal dos direitos da criança da ONU: indivíduos até aos 17 anos (inclusive). Contudo, como tem sido chamado a atenção na literatura, esta definição implica colocar na mesma categoria indivíduos em fases da vida muito distintas do ponto de vista biológico e social (compare-se um indivíduo de 3 anos com um de 15). Também acaba por sobrepor-se com outras definições e idades da vida, desde logo, a juventude, a adolescência e até a idade adulta. 
Contudo, utiliza-se habitualmente o intervalo etário dos 0 aos 17 anos usando os mesmos argumentos que permitem que se fale de pobreza infantil. Em primeiro lugar, um argumento tautológico: o conceito e o intervalo de idades permitem a comparabilidade com outros estudos; em segundo, pode-se falar de pobreza infantil pelas mesmas razões que se pode falar de infância: as crianças são social e economicamente dependentes dos mais velhos estando até legalmente impedidas de trabalhar e, além disso, boa parte dos indivíduos considerados neste intervalo de idades não têm ainda maturidade biológica para procriar.

Em terceiro lugar, a pobreza é muito mais do que a escassez de recursos (embora esta seja uma condição para se ser pobre), e se as crianças não são titulares de recursos apresentam outros atributos que permitem a sua classificação como pobres (e eventualmente como excluídos) (Diogo, 2018).

Em termos concretos, o que sabemos sobre a pobreza infantil em Portugal é verdadeiramente pouco. Existem alguns estudos empíricos e muito poucos investigadores dedicados ao assunto. Em termos institucionais apenas a Rede Europeia Anti-Pobreza (EAPN) apresenta um grupo de trabalho sobre a pobreza infantil (Sarmento \& Veiga, 2010). Mais recentemente, foi constituído o ProChild CoLAB na Universidade do Minho.

Os dados de base para os estudos sobre a pobreza infantil são os fornecidos pelo Instituto Nacional de Estatística (INE) respeitando na sua totalidade aos resultados de um inquérito anual, o Inquérito às Condições de Vida e Rendimento/Statistics on Income and Living Conditions (ICOR EU-SILC), desenvolvido em articulação com o Eurostat. Estão disponíveis dados desde 2003. Estes mostram que a taxa de pobreza (taxa de risco de pobreza no léxico do Eurostat) é sempre maior para as crianças (0-17 anos) do que a taxa geral. Para além da pobreza por grupos de idade, o INE apresenta dados por tipo de família (ADP). Nesta variável destacam-se como sendo mais pobres as famílias com crianças, em particular um adulto com uma criança (identificados na literatura com sendo sobretudo famílias monoparentais femininas), dois adultos com três ou mais crianças, bem como a categoria outros agregados com crianças.

Em relação aos estudos já realizados usando os dados do INE salienta-se o facto de as transferências sociais para a infância, ou que incluam a infância, não terem um impacto significativo na redução da pobreza infantil em contraste com um elevado impacto na redução da pobreza dos idosos. 
A taxa de pobreza infantil tem vindo a reduzir-se e a aproximar-se da média. Contudo, ao longo dos anos verifica-se que cerca de um quarto a um quinto das crianças portuguesas vive em situação de pobreza, no contexto de um país onde não nascem crianças suficientes para se fazer a substituição das gerações. Por si só, este último dado justifica a centralidade da questão na sociedade portuguesa.

\section{Child Poverty}

Child poverty is a complex and central issue in Portuguese society, as in other European societies.

Its complexity is associated with the controversy surrounding its definition and is primarily an epistemological issue. Indeed, some scholars on poverty reject the idea of child poverty, preferring to talk about the poverty of children.

This controversy is rooted in an important idea: children are not income earners; they are poor within poor households. This argument stems from the way poverty is calculated in the European Union (EU). Therefore, Eurostat considers as poor all individuals with an income below $60 \%$ of median equalised national income. This means that income data from which poverty is calculated is collected by Private Household $(\mathrm{PH})$ and then individualized according to an equivalent adult scale (modified OECD).

This conversion process poses a new problem that challenges the definition of child poverty: it presupposes the equal distribution of resources in the household, which, according to the literature, tends to underestimate the poverty of children and women (Bastos, 2015).

In addition, the definition of child poverty is challenged by other factors. Firstly, because it results from the juxtaposition of two concepts, poverty and childhood, which are complex in themselves. A significant illustration of these difficulties has to do with the age definition of children. Studies on child poverty tend to mobilize the definition of the UN Universal Convention of the Rights of the Child: individuals up to 17 years old. However, as attention has been drawn in the literature, this definition implies placing in the same category individuals at very different biological and social stages of life (compare a 3-year-old to a 15-year-old). It also overlaps with other definitions and ages of life, such as youth, adolescence, and even adulthood. 
However, the age range from 0 to 17 years is usually used employing the same arguments that allow for child poverty. Firstly, a tautological argument: the concept and age range allow comparison with other studies; secondly, one can speak of child poverty for the same reasons as one can speak about childhood: children are socially and economically dependent on their elders and are even legally prevented from working. Furthermore, most of the individuals considered in this age range do not have the biological maturity to have offspring.

Thirdly, poverty is much more than a scarcity of resources (although this is a condition for being poor), and if children are not resource holders, they have other attributes that allow them to be classified as poor (and eventually as excluded) (Diogo, 2018).

In concrete terms, what we know about child poverty in Portugal is very little. There are some empirical studies and very few researchers dedicated to the subject. In institutional terms only, the European Anti-Poverty Network (EAPN) presents a working group on child poverty (Sarmento \& Veiga, 2010). More recently the ProChild CoLAB was created at the University of Minho.

The baseline data for child poverty studies are those provided by the National Institute of Statistics (INE) in full compliance with the results of an annual survey, the Statistics on Income and Living Conditions Survey (ICOR EU-SILC), developed in conjunction with Eurostat. Data has been available since 2003. These show that the poverty rate (at poverty risk rate in the Eurostat lexicon) is always higher for children (0-17 years) than the overall rate. In addition to poverty by age group, INE presents data by type of family $(\mathrm{PH})$. In this variable, families with children stand out as being poorer, in particular one adult with one child (identified in the literature as being mainly women single parent families), two adults with three or more children, as well as the category other households with children.

In studies conducted using INE data, it should be noted that social transfers to childhood, or that include childhood, do not have a significant impact on reducing child poverty, in contrast to a high impact on poverty reduction in the case of the elderly.

The child poverty rate has been falling and approaching the average. However, over the years it has been found that about one quarter to one fifth of Portuguese children live in poverty, in the context of a country where not enough children are born to ensure the continuity of generations. This 
last statistic alone justifies the extreme importance of the issue in Portuguese society.

\section{Referências / References}

Bastos, A. (2015). Pobreza infantil. Diagnóstico e reflexão sobre os indicadores de aferição. In F. Diogo, A. Castro \& P. Perista (Eds.) (2015). Pobreza e exclusão social em Portugal: contextos, transformações e estudos (pp. 101-113). Ribeirão: Húmus.

Diogo, F. (2018). A pobreza infantil e o Rendimento Social de Inserção em Portugal: o mesmo problema tendências distintas. Sociologia: Problemas e Práticas, 87, 71-86.

Sarmento, M. J. \& Veiga, F. (Ed.) (2010). Pobreza infantil: realidades, desafios, propostas, Ribeirão: Húmus. 